\title{
Hepatitis D virus infection in Slovenian patients with chronic hepatitis B virus infection: a national prevalence study and literature review
}

\author{
Mateja M. Jelen ${ }^{1}$, Lea Hošnjak² ${ }^{2}$ Špela Štunf ${ }^{3}$, Anja Zagožen ${ }^{2}$, Kristina Fujs Komloš², Petra Markočič ${ }^{2}$, Mario Poljak², Katja \\ Seme $^{2 凶}$
}

\begin{abstract}
Introduction: Of the 350 million individuals chronically infected with hepatitis B virus (HBV) worldwide, approximately 15 to 20 million have been exposed to hepatitis D virus (HDV). This study determined for the first time the HDV prevalence in Slovenian patients with chronic HBV infection. In addition, a literature search was performed to identify all HDV prevalence studies from European countries.

Methods: A total of 1,305 HBsAg-positive serum samples, obtained from the same number of patients, were randomly selected from 2,337 patients referred to the Slovenian national reference laboratory for viral hepatitis between 1998 and 2015 . All samples were retrospectively tested for the presence of total anti-HDV antibodies. Anti-HDV-positive patients were additionally tested for the presence of anti-HDV IgM antibodies, HDV antigen, and HDV RNA.

Results: Total anti-HDV antibodies were detected in three of the 1,305 patients tested (0.23\%; $95 \% \mathrm{Cl}: 0.08-0.67 \%)$, of whom one patient had recovered from the past HDV infection and two patients had an ongoing chronic HDV infection. The literature search identified 36 peer-reviewed HDV prevalence studies published between 1983 and 2016 and originating from 21 European countries. Conclusion: The observed prevalence of HDV infection in Slovenia was among the lowest reported in Europe and worldwide. Due to the observed low prevalence of HDV infection, routine diagnostic testing for HDV should not be considered in differential diagnosis of exacerbation of liver disease in Slovenian patients with chronic HBV infection.
\end{abstract}

Keywords: hepatitis D virus, prevalence, acute HDV infection, chronic HDV infection, Slovenia, Europe

Received: 24 June 2016 | Returned for modification: 12 July 2016 | Accepted: 27 July 2016

\section{Introduction}

Hepatitis D virus (HDV), the only representative of the family Deltaviridae, is one of the five primary etiological agents of viral hepatitis. HDV is an incomplete satellite virus that can replicate only in cells concomitantly infected with hepatitis B virus (HBV) because its envelope consists of HBV surface antigens (HBsAg) and lipids from the host cell (1). HDV is mostly transmitted parenterally, with the highest transmission rates in injecting drug users and individuals exposed to infected blood or blood products (2-4). In addition, intra-familiar transmission in hyper-endemic regions (4) and sexual transmission are also described $(5,6)$. Upon co-infection with HBV and HDV, acute hepatitis is usually followed by a resolution of both HBV and HDV infections. However, super-infection with HDV usually results in chronic hepatitis caused by both viruses. In comparison to patients with chronic hepatitis B, patients with chronic hepatitis B and D are significantly more likely to develop cirrhosis, liver decompensation, and hepatocellular carcinoma $(4,7,8)$.

Of the 350 million individuals chronically infected with HBV worldwide, approximately 15 to 20 million have been exposed to HDV infection $(9,10)$. Interestingly, the prevalence of HDV infection varies greatly across different geographic regions and does not exactly match the distribution of patients with chronic HBV infection $(11,12)$. As a result of vaccination against HBV, mandatory testing of blood donors, improvements in sanitation, and behavioral changes, HDV prevalence has decreased in the last 20 years in the majority of European countries, especially in southern Europe (13). However, it has recently begun rising again in some European countries, such as France, Germany, Spain, and the United Kingdom, due to immigration from endemic areas (mainly from Africa, eastern Europe, and Turkey) (2, 14-19).

Slovenia is a country with a population of approximately two million and an estimated HBV prevalence of less than $5 \%$. To the best of our knowledge, no reports on HDV prevalence in Slovenia have been published to date in the peer-reviewed literature. Thus, the main aim of our study was to determine the HDV prevalence in Slovenian patients with chronic HBV infection. In addition, to compare our results with existing published data, a literature search was performed to identify all HDV prevalence studies originating from European countries. A literature search was performed on June 1oth, 2016. Eligible peer-reviewed studies, with no bias toward articles written in English, published between 1983 and 2016 were searched through the MEDLINE/PubMed, Web of Science, Scopus, and Google Scholar databases using a combination of the following terms: hepatitis D virus, HDV, HDV antibodies, prevalence, and Europe.

\section{Material and methods}

This study included 1,305 HBsAg-positive serum samples obtained from the same number of patients randomly selected from all 2,337 patients with chronic hepatitis B referred to the Slovenian national reference laboratory for viral hepatitis at the Institute of Microbiology and Immunology, Faculty of Medicine, University of Ljubljana, between February 1998 and December 2015 (Fig. 1). Information on sex, age, and place of residence was available for all 1,305 patients tested; our study group comprised 792 men (60.7\%) 
and 513 women (39.3\%). The mean age for men and women at diagnosis of chronic hepatitis B was 45.5 and 43.3 years, respectively. Considering the $95 \%$ confidence interval and $2.5 \%$ margin of error, our sample size was representative for all patients with chronic HBV infection in Slovenia.

The selected HBsAg-positive serum samples were retrospectively tested for the presence of total anti-HDV antibodies using the commercially available enzyme-linked immunosorbent assay ETI-AB-DELTAK-2 (DiaSorin, Saluggia, Italy) with 99.0\% (95\% confidence interval; CI: 97.8-99.6\%) clinical specificity and 99.4\% (95\% CI: 96.8-100\%) clinical sensitivity for detection of total anti-HDV antibodies, as declared by the manufacturer. Additional serum samples were retrieved from all anti-HDV-positive individuals and retrospectively tested for the presence of antiHDV IgM and HDV-Ag using the commercially available enzyme immunoassays ETI-DELTA-IGMK-2 (DiaSorin) and ETI-DELTAK-2 (DiaSorin), respectively. According to the manufacturer, ETI-DELTA-IGMK-2 (DiaSorin) and ETI-DELTAK-2 (DiaSorin) have a clinical specificity of $99.0 \%$ (95\% CI: $97.9-99.6 \%)$ and $99.0 \%(95 \%$ CI: 98.0-99.6\%), respectively, and a clinical sensitivity of $99.5 \%$ (95\% CI: 97.4-100\%) and 100\% (95\% CI: 87.2-100\%), respectively. All serology-based methods were performed strictly following the manufacturer's instructions.

For detecting HDV viremia, total nucleic acids were extracted from all anti-HDV-positive serum samples using the commercially

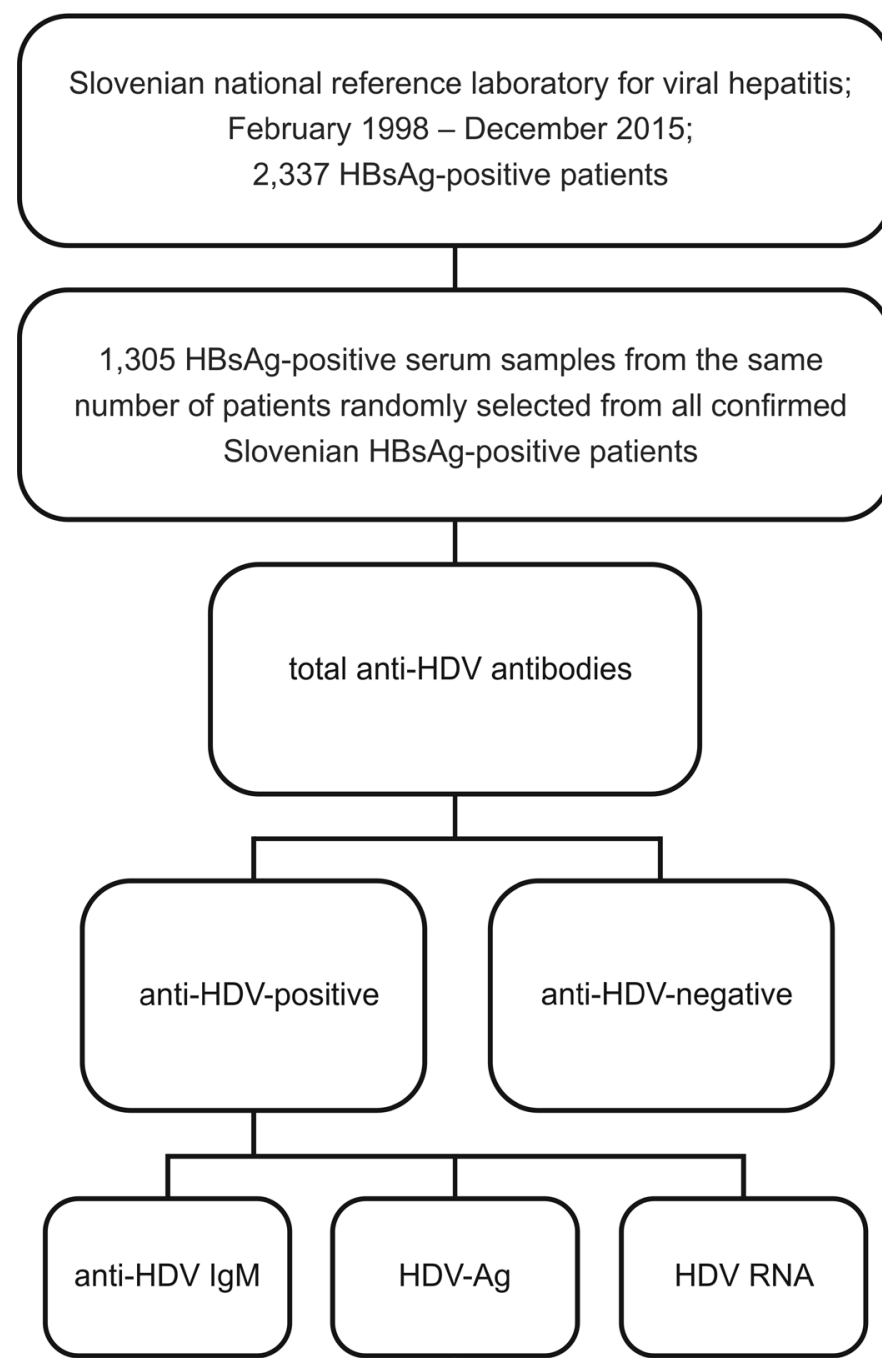

Figure 1 | Overview of the study protocol. Between February 1998 and December 2015, 2,337 HBsAg-positive patients were followed by the Slovenian reference laboratory for viral hepatitis. Among all HBsAg-positive patients, 1,305 patients were randomly selected for total anti-HDV antibody testing. All antiHDV-positive patients were further tested for the presence of anti-HDV IgM antibodies (anti-HDV IgM), hepatitis D antigen (HDV-Ag) and HDV RNA. available MagNA Pure Compact Nucleic Acid Isolation Kit I (Roche Diagnostics, Mannheim, Germany) on the MagNA Pure Compact Instrument (Roche Diagnostics), following our in-house protocol. Briefly, prior to automatic extraction of nucleic acids using a Total_NA_Plasma_external_lysis protocol, an external lysis of each serum sample $(200 \mu \mathrm{l})$ was performed using $300 \mu$ l of MagNA Pure LC Total Nucleic Acid Isolation Kit - Lysis/Binding Buffer Refill (Roche Diagnostics) and 30-minute incubation at $25^{\circ} \mathrm{C}$ and 350 rpm. Total nucleic acids were eluted in $100 \mu \mathrm{l}$ of elution buffer and stored (in $10 \mu \mathrm{l}$ aliquots) at $-20^{\circ} \mathrm{C}$. In all samples, the quality/ integrity of the extracted RNA was verified by amplification of the 85-bp fragment of human ribosomal RNA (rRNA), encoding the S9 protein, using primers (RibPS9-F and RibPS9-R) and a probe (RibPS9-Probe) previously published (20). The RibPS9 reversetranscription real-time PCR was conducted using LightCycler 480 RNA Master Hydrolysis Probes (Roche Diagnostics) in a $25 \mu \mathrm{l}$ reaction mixture, consisting of $5 \mu \mathrm{l}$ of template RNA, $7.4 \mu \mathrm{l}$ of $2.7 \times$ LightCycler 480 RNA Master Hydrolysis Probes, $1.3 \mu$ lof Activator (50 mM), $1 \mu \mathrm{l}$ of $20 \times$ Enhancer, $0.5 \mu \mathrm{M}$ of each primer, $0.2 \mu \mathrm{M}$ of the TaqMan probe, and water. The test was performed on the LightCycler 480 II RT-PCR Instrument (Roche Diagnostics) under the following conditions: $3 \mathrm{~min}$ at $63{ }^{\circ} \mathrm{C}\left(4.4^{\circ} \mathrm{C} / \mathrm{s}\right), 30 \mathrm{~s}$ at $95^{\circ} \mathrm{C}(4.4$ $\left.{ }^{\circ} \mathrm{C} / \mathrm{s}\right)$, followed by 45 cycles of $15 \mathrm{~s}$ at $95^{\circ} \mathrm{C}\left(4.4^{\circ} \mathrm{C} / \mathrm{s}\right), 1 \mathrm{~min}$ at 60 ${ }^{\circ} \mathrm{C}\left(2.2^{\circ} \mathrm{C} / \mathrm{s}\right)$, and $1 \mathrm{~s}$ at $72{ }^{\circ} \mathrm{C}\left(4.4^{\circ} \mathrm{C} / \mathrm{s}\right)$, and a final $10 \mathrm{~s}$ cooling of the reaction mixture at $40^{\circ} \mathrm{C}\left(2.2^{\circ} \mathrm{C} / \mathrm{s}\right)$. Only RibPS9-positive samples were used in downstream determination of the presence of HDV RNA. The in-house HDV reverse-transcription real-time PCR (HDV rt-RT-PCR), enabling amplification of a 71-bp fragment of the conserved genomic region encoding HDV-Ag, was performed using primers (HDV-F1, HDV-F2, and HDV-R) and a probe (HDVprobe) $(21,22)$ previously published, following the same protocol as described above, with the exception of annealing temperature, which was set to $55^{\circ} \mathrm{C}$. Based on the testing of HDV-RNA-positive clinical samples with known concentrations of viral RNA (30011,000,000 viral copies/ml), the analytical sensitivity of the HDV rt-RT-PCR was estimated to be at least 300 viral copies $/ \mathrm{ml}$.

Information on HBV viral load was retrieved from the database of the Slovenian national reference laboratory for viral hepatitis.

\section{Results}

Total anti-HDV antibodies were detected in three of 1,305 patients with chronic HBV infection (0.23\%; 95\% CI: 0.08-0.67\%). In a 48-year-old male patient, except for total anti-HDV antibodies, no other HDV infection markers were detected in any of the samples tested, suggesting resolved HDV infection in this patient (patient 1, Table 1). In contrast, anti-HDV IgM antibodies and HDV RNA were detected in all samples tested obtained from a 28 -year-old female patient and a 6o-year-old male patient (patients 2 and 3, Table 1) suggesting ongoing chronic HDV infection in both patients. Interestingly, HDV-Ag could not be detected in any serum samples from both patients with ongoing HDV infection. All three anti-HDV antibody-positive patients tested negative for the presence of human immunodeficiency virus (HIV) infection and were generally considered to be immunocompetent.

\section{Discussion}

A literature search on HDV prevalence studies from European countries, performed on July 10th, 2016, resulted in 36 peer-reviewed studies from 21 European countries (Table 2). According to this search, Slovenia was one of the few remaining European 
countries with no reports on HDV prevalence published in the peer-reviewed literature. In this study, total anti-HDV antibodies were detected in 3/1,305 (0.23\%; 95\% CI: 0.08-0.67\%) Slovenian patients with chronic HBV infection. Our results could be considered representative for all patients with chronic HBV infection in Slovenia, considering the $95 \%$ confidence interval and $2.5 \%$ margin of error. Even though information on sex, age, and place of residence was available for all patients in the study, the low rate of HDV positivity prevented the analysis of a possible relationship between anti-HDV positivity and patients' characteristics.

As a result of vaccination against $\mathrm{HBV}$, mandatory testing of blood donors, improvements in sanitation, and behavioral changes, HDV prevalence has decreased in the last 20 years in the majority of European countries, especially in southern Europe (13). In several cross-sectional studies, which included hundreds of HBsAg-positive individuals with liver disease, the HDV prevalence in Italy was estimated at $24.7 \%$ in $1981,23.4 \%$ in 1987 , $14.4 \%$ in $1992,8.3 \%$ in 1997 , and $8.1 \%$ in 2007 (23-27). However, since 2007 no further decrease in HDV prevalence was recorded in Italy, with steady prevalence rates of $8.4 \%$ among HBsAg carriers (28). Of note, the reported prevalence of HDV infection was lower, ranging from 1.3 to $5.0 \%$ in Italians and from 4.7 to $7.9 \%$ in immigrants, in studies providing data from limited geographic regions $(29,30)$. Unlike several HDV prevalence studies in Italy, the data on HDV prevalence in the other three countries bordering Slovenia are scant and outdated because they date back to 1985, 1993, and 1994, respectively (31-33). Thus, the prevalence of HDV infection in Austria, Croatia, and Hungary was estimated at $2.9 \%$ (HBsAg carriers), $19.0 \%$ (chronic HBsAg carriers), and 13.6\% (chronic HBsAg carriers), respectively (31-33). Even though a more thorough comparison of HDV prevalence is hampered due to outdated information from the majority of countries bordering Slovenia and the use of HDV diagnostic tests with different analytical characteristics in prevalence surveys in different countries, it seems that the HDV prevalence in Slovenian patients with chronic HBV infection is among the lowest in southern Europe. The low prevalence of HDV infection may be attributable to the low HBV burden in Slovenia, which reflects broad HBV vaccination coverage and mandatory testing of blood donors, pregnant women, and family members and partners of HBsAg-positive individuals. It is noteworthy that in Slovenia the national HBV vaccination program started in 1983 and continued to expand until 1998, when HBV vaccination of preschool children was added to the national vaccination schedule. Interestingly, Italy's incidence of acute HBV (1 per 100,000) is similar to that of Slovenia (o.8 per $100,000)$ and Italy established a HBV vaccination program for neonates and 12-year-olds in 1991 (34, 35); however, in comparison to Slovenia, the prevalence of HDV infection in still significantly higher in Italy. It appears that in Europe HDV is sustained by two different residual pools of HDV-infected patients: (i) young individuals that are migrating from HDV endemic areas and (ii) older individuals that were infected with HDV during the 1980 s epidemics (also referred to as the domestic pool) $(2,8,36)$. Without accurate epidemiologic data, one can only speculate that the observed difference in HDV prevalence between Slovenia and Italy is a consequence of an existing reservoir of HDV-positive individuals that were infected during the 1980 s epidemics in Italy. Moreover, the higher HDV prevalence in Italy could also be attributable to differences in risky behavior among HDV-positive individuals in both countries, such as drug abuse or promiscuous sexual practices.

In contrast to southern Europe, HDV prevalence has recently begun to rise again in other European countries, such as France, Germany, Spain, and the United Kingdom, due to immigration from endemic areas (mainly from Africa, eastern Europe, and Turkey) (2, 14-19). With on-going globalization and the influx of immigrants from less-developed endemic countries, where HBV is not controlled through vaccination and screening, regular epidemiological surveillance of HDV prevalence in Slovenia is also recommended in the near future.

To evaluate whether differences in HDV prevalence across European countries could be at least partially attributed to the use of anti-HDV antibody tests with different analytical characteristics (mainly different analytical specificity), the material and methods sections of published studies (Table 2) were carefully analyzed. Out of 36 eligible studies, the commercially available enzymelinked immunosorbent assay ETI-AB-DELTAK-2 (DiaSorin) was used in nine studies $(14,16,19,30,37-41)$ and the Abbott anti-HD radioimmunoassay (Abbott Laboratories, Chicago, IL) and Radim anti-HDVAb (Radim Iberica, Barcelona, Spain) were used in one study each $(17,29)$. Unfortunately, tests used for detecting antiHDV antibodies were not specified in the majority of eligible studies. In addition, due to the wide timespan of eligible studies (published from 1983 to 2016), we were unable to associate reported HDV prevalence rates with the use of specific diagnostic test(s) for detecting anti-HDV antibodies.

Table 1 | Characteristics of three anti-HDV-positive patients: one patient with past HDV infection (patient 1) and two patients with ongoing chronic HDV infection (patients 2 and 3 ).

\begin{tabular}{|c|c|c|c|c|c|c|c|c|c|c|}
\hline \multirow[b]{2}{*}{$\begin{array}{l}\text { Patient } \\
\text { no. }\end{array}$} & \multirow[b]{2}{*}{ Sex } & \multirow[b]{2}{*}{$\begin{array}{l}\text { Age } \\
\text { at diagnosis }\end{array}$} & \multirow[b]{2}{*}{ Place of residence } & \multirow{2}{*}{$\begin{array}{c}\text { Sample no. } \\
\text { (date: } \mathrm{mm} / \mathrm{dd} / \mathrm{yyyy})\end{array}$} & \multicolumn{2}{|c|}{ HBV infection markers } & \multirow[b]{2}{*}{$\begin{array}{c}\text { Total } \\
\text { anti-HDV Ab }\end{array}$} & \multicolumn{2}{|c|}{ HDV infection markers } & \multirow[b]{2}{*}{ HDV RNA } \\
\hline & & & & & $\mathrm{HBsAg}$ & $\begin{array}{c}\text { HBV DNA } \\
(\mathrm{IU} / \mathrm{ml})\end{array}$ & & HDV-Ag & anti-HDV IgM & \\
\hline \multirow[t]{3}{*}{1} & M & 48 & Ljubljana & $1(03 / 14 / 2000)$ & positive & $\mathrm{N} / \mathrm{A}$ & positive & negative & negative & negative \\
\hline & & & & $2(03 / 23 / 2000)$ & positive & $\mathrm{N} / \mathrm{A}$ & positive & negative & negative & negative \\
\hline & & & & $3(12 / 17 / 2001)$ & positive & 353 & positive & negative & negative & negative \\
\hline \multirow[t]{4}{*}{2} & $\mathrm{~F}$ & 28 & Kranj & $1(11 / 07 / 2008)$ & positive & $\mathrm{N} / \mathrm{A}$ & positive & negative & positive & positive \\
\hline & & & & $2(11 / 11 / 2008)$ & positive & 232 & positive & negative & positive & positive \\
\hline & & & & $3(02 / 03 / 2009)$ & positive & 1,020 & positive & negative & positive & positive \\
\hline & & & & $4(12 / 08 / 2009)$ & positive & $<6$ & positive & negative & positive & positive \\
\hline \multirow[t]{7}{*}{3} & $M$ & 60 & Postojna & $1(10 / 10 / 2007)$ & positive & 65 & positive & negative & positive & positive \\
\hline & & & & $2(09 / 17 / 2008)$ & positive & 34 & positive & negative & positive & positive \\
\hline & & & & $3(10 / 20 / 2009)$ & positive & 58 & positive & negative & positive & positive \\
\hline & & & & $4(02 / 01 / 2011)$ & positive & 370 & positive & negative & positive & positive \\
\hline & & & & $5(05 / 24 / 2011)$ & positive & 68,452 & positive & negative & positive & positive \\
\hline & & & & $6(09 / 05 / 2011)$ & positive & 646 & positive & negative & positive & positive \\
\hline & & & & $7(12 / 06 / 2011)$ & positive & $<15$ & positive & negative & positive & positive \\
\hline
\end{tabular}

Note: total anti-HDV Ab = total anti-HDV antibodies, anti-HDV IgM = anti-HDV IgM antibodies, HDV-Ag $=$ hepatitis D antigen, N/A = not analyzed 
Table 2 | Prevalence of HDV infection in European countries (1983-2016) according to a literature search performed on July 10 th, 2016.

\begin{tabular}{|c|c|c|c|c|}
\hline Country & Tested population (time period) & $\begin{array}{l}\text { HDV infection } \\
\text { marker(s) tested }\end{array}$ & $\begin{array}{c}\text { HDV prevalence; number of } \\
\text { positives / samples tested } \\
\text { (\% positives) }\end{array}$ & Reference \\
\hline Albania & $\begin{array}{l}\text { patients with chronic viral and/or } \\
\text { alcohol-induced liver disease } \\
\text { (1995 and 2005) }\end{array}$ & total anti-HDV Ab & $\begin{array}{c}\text { 1995: 10/106 (9.4\%); } \\
\text { 2005: 7/99 (7.1\%) }\end{array}$ & Kondili et al., 2010 (43) \\
\hline
\end{tabular}

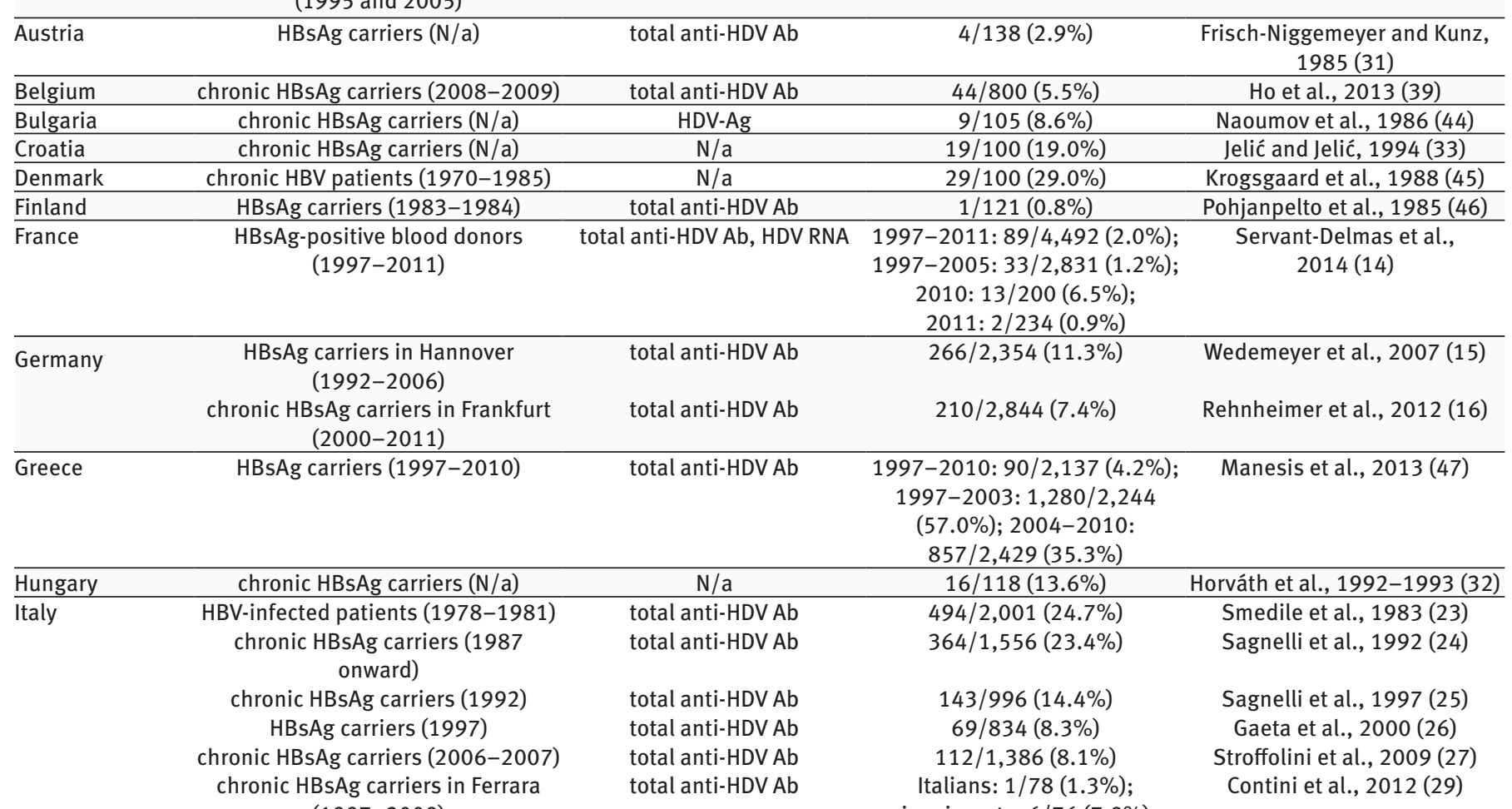
(1997-2009)

HBsAg carriers in Milan (2007-2008) HBsAg carriers $(\mathrm{N} / \mathrm{a})$

total anti-HDV Ab total anti-HDV Ab immigrants: 6/76 (7.9\%) Italians: 19/381 (5.0\%); immigrants: 5/107 (4.7\%) Italians: 53/716 (7.4\%); immigrants: 34/295 (11.5\%)

\begin{tabular}{|c|c|c|c|c|}
\hline Kosovo & $\begin{array}{l}\text { general population (healthcare work- } \\
\text { ers, pregnant women, blood donors, } \\
\text { patients included in routine blood } \\
\text { testing) (2005) }\end{array}$ & anti-HDV IgG & $1 / 1,287(0.08 \%)$ & Quaglio et al., 2008 (38) \\
\hline Poland & $\begin{array}{l}\text { chronic HBV patients }(\mathrm{N} / \mathrm{a}) \\
\text { chronic HBsAg carriers in the north- } \\
\text { ern part of the country }(2002-2004)\end{array}$ & $\begin{array}{c}\text { total anti-HDV Ab } \\
\text { total anti-HDV Ab, HDV RNA }\end{array}$ & $\begin{array}{c}4 / 102(3.9 \%) \\
\text { total anti-HDV Ab: } 3 / 63(4.8 \%) ; \\
\text { HDV RNA: } 5 / 63(7.9 \%)\end{array}$ & $\begin{array}{l}\text { Chlabicz et al., } 2003 \text { (48) } \\
\text { Bielawski et al., } 2006 \text { (37) }\end{array}$ \\
\hline Portugal & chronic HBsAg carriers $(\mathrm{N} / \mathrm{a})$ & $\mathrm{N} / \mathrm{a}$ & $\mathrm{N} / \mathrm{a}(17.3 \%)$ & Ramalho et al., 1987 (49) \\
\hline Romania & chronic HBsAg carriers (2005) & anti-HDV IgG, HDV RNA & $223 / 1,094(20.4 \%)$ & Popescu et al., 2013 (50) \\
\hline $\begin{array}{l}\text { Serbia and } \\
\text { Montenegro }\end{array}$ & HBsAg carriers $(\mathrm{N} / \mathrm{a})$ & total anti-HDV Ab & $69 / 614(11.2 \%)$ & Delić et al., 1993 (51) \\
\hline \multirow[t]{3}{*}{ Spain } & $\begin{array}{l}\text { immigrants (HBsAg carriers) from } \\
\text { Equatorial Guinea (2002-2008) }\end{array}$ & total anti-HDV Ab & $249 / 1,220(20.4 \%)$ & Rivas et al., 2013 (17) \\
\hline & HIV-positive patients (2004 onward) & total anti-HDV Ab & $17 / 1,147(1.5 \%)$ & $\begin{array}{l}\text { Fernández-Montero et al., } \\
2014 \text { (52) }\end{array}$ \\
\hline & $\begin{array}{c}\text { African immigrants (HBsAg carriers) } \\
\text { treated by specialists }(\mathrm{N} / \mathrm{a})\end{array}$ & total anti-HDV Ab & $1,984 / 2,518(78.8 \%)$ & Cuenza-Gómez et al., 2016 (18) \\
\hline Sweden & chronic HBsAg carriers (1997-2008) & $\mathrm{N} / \mathrm{a}$ & $650 / 9,160(7.1 \%)$ & Ji et al., 2012 (53) \\
\hline \multirow[t]{2}{*}{ Switzerland } & $\begin{array}{l}\text { chronic HBV patients } \\
\text { (mostly immigrants) }(\mathrm{N} / \mathrm{a})\end{array}$ & $\begin{array}{c}\text { total anti-HDV Ab/ anti-HDV } \\
\text { IgM/ anti-HDV IgG/ HDV-Ag/ } \\
\text { HDV RNA }\end{array}$ & $101 / 1,699(5.9 \%)$ & Genné and Rossi, 2011 (3) \\
\hline & HBsAg carriers (2002-2013) & total anti-HDV Ab & $15 / 338(4.4 \%)$ & Hirzel et al., 2015 (41) \\
\hline \multirow[t]{4}{*}{ United Kingdom } & $\begin{array}{c}\text { HBsAg carriers (1970-1989) in } \\
\text { Northern Ireland }\end{array}$ & total anti-HDV Ab & 9/401 (2.2\%) & Curran et al., 1989 (54) \\
\hline & $\begin{array}{l}\text { chronic HBV patients (mostly immi- } \\
\text { grants) }(2000-2006) \text { in London }\end{array}$ & total anti-HDV Ab & $82 / 962(8.5 \%)$ & Cross et al., 2008 (2) \\
\hline & $\begin{array}{l}\text { HBsAg carriers (2008-2012) in } \\
\text { London }\end{array}$ & $\begin{array}{c}\text { total anti-HDV Ab, anti-HDV } \\
\text { IgM, HDV RNA }\end{array}$ & $22 / 1,048(2.1 \%)$ & William Tong et al., 2013 (40) \\
\hline & $\begin{array}{l}\text { HBsAg carriers (mostly immigrants) } \\
(2005-2012) \text { in London }\end{array}$ & total anti-HDV Ab & $162 / 3,610(4.5 \%)$ & El Bouzidi et al., 2015 (19) \\
\hline
\end{tabular}

De Paschale et al., 2012 (30)

Brancaccio et al., 2014 (28)

Quaglio et al., 2008 (38)

Note: total anti-HDV Ab = total anti-HDV antibodies, anti-HDV IgM = anti-HDV IgM antibodies, anti-HDV IgG = anti-HDV IgG antibodies, HDV-Ag $=$ hepatitis D antigen, $\mathrm{N} / \mathrm{a}=$ not available 
In this study, total anti-HDV antibodies were detected in only three patients: in one patient that recovered from a past HDV infection and in two patients with an ongoing chronic HDV infection. Interestingly, HDV-Ag could not be detected in any serum samples of both patients with ongoing HDV infection (Table 1). This is in accordance with previously published studies reporting that in immunocompetent individuals HDV-Ag is frequently neutralized by anti-HDV antibodies and thus not detectable (10, 42). In contrast, HDV-Ag is usually detected in serum samples obtained from immunocompromised patients chronically infected with HDV (10, 42).

In conclusion, in the first Slovenian national prevalence study the observed prevalence of HDV infection was among the lowest reported in Europe and worldwide. The low HDV prevalence in Slovenia is most likely a result of successful prevention of HBV infection with mandatory testing of blood donors, pregnant women, and family members and partners of HBsAg-positive individuals and universal vaccination against hepatitis B. Due to the observed low prevalence of HDV infection, routine diagnostic testing for
HDV should not be considered in differential diagnosis of exacerbation of liver disease in Slovenian patients with chronic HBV infection. However, regular epidemiological surveillance of HDV prevalence in Slovenia is still recommended.

\section{Funding}

No funding was received for conducting this study.

\section{Conflict of interest}

The authors have no conflicts of interest to declare.

\section{Acknowledgements}

The authors thank Boštjan Kocjan for optimizing reverse-transcription real-time PCR protocols for amplification of RibPS9 and HDV RNA.

\section{References}

1. Sureau C. The role of HBV envelope proteins in the HDV replication cycle. Curr Top Microbiol Immunol. 2006;307:113-31.

2. Cross TJS, Rizzi P, Horner M, Jolly A, Hussain MJ, Smith HM, et al. The increasing prevalence of hepatitis delta virus (HDV) infection in South London. J Med Virol. 2008;80:277-82.

3. Genné D, Rossi I. Hepatitis delta in Switzerland: a silent epidemic. Swiss Med Wkly. 2011;141:W13176.

4. Hughes SA, Wedemeyer H, Harrison PM. Hepatitis delta virus. Lancet. 2011;378: $73-85$.

5. Rosenblum L, Darrow W, Witte J, Cohen J, French J, Gill PS, et al. Sexual practices in the transmission of hepatitis $B$ virus and prevalence of hepatitis delta virus infection in female prostitutes in the United States. JAMA. 1992;267:2477-81.

6. Wu JC, Chen CM, Sheen IJ, Lee SD, Tzeng HM, Choo KB. Evidence of transmission of hepatitis $D$ virus to spouses from sequence analysis of the viral genome. Hepatology. 1995;22:1656-60.

7. Smedile A, Farci P, Verme G, Caredda F, Cargnel A, Caporaso N, et al. Influence of delta infection on severity of hepatitis B. Lancet. 1982;2:945-7.

8. Rizzetto M. Hepatitis D: thirty years after. J Hepatol. 2009;50:1043-50.

9. Ciancio A, Rizzetto M. Chronic hepatitis $D$ at a standstill: where do we go from here? Nat Rev Gastroenterol Hepatol. 2014;11:68-71.

10. Alfaiate D, Dény P, Durantel D. Hepatitis delta virus: from biological and medical aspects to current and investigational therapeutic options. Antiviral Res. 2015;122:112-29.

11. Rizzetto M, Purcell RH, Gerin JL. Epidemiology of HBV-associated delta agent: geographical distribution of anti-delta and prevalence in polytransfused $\mathrm{HBsAg}$ carriers. Lancet. 1980;1:1215-8.

12. Ponzetto A, Forzani B, Parravicini PP, Hele C, Zanetti A, Rizzetto M. Epidemiology of hepatitis delta virus (HDV) infection. Eur J Epidemiol. 1985;1:257-63.

13. Rizzetto M, Ciancio A. Epidemiology of hepatitis D. Semin Liver Dis. 2012;32:211 9.

14. Servant-Delmas A, Le Gal F, Gallian P, Gordien E, Laperche S. Increasing prevalence of HDV/HBV infection over 15 years in France. J Clin Virol. 2014;59:126-8.

15. Wedemeyer H, Heidrich B, Manns MP. Hepatitis D virus infection - not a vanishing disease in Europe! Hepatology. 2007;45:1331-2.

16. Reinheimer C, Doerr HW, Berger A. Hepatitis delta: on soft paws across Germany. Infection. 2012;40:621-5.

17. Rivas P, Herrero MD, Poveda E, Madejón A, Treviño A, Gutiérrez M, et al. Hepatitis $B, C$, and D and HIV infections among immigrants from Equatorial Guinea living in Spain. Am J Trop Med Hyg. 2013;88:789-94.

18. Cuenza-Gómez JA, Salas-Coronas J, Soriano-Pérez MJ, Vázquez-Villegas J, Lozano-Serrano AB, Cabezas-Fernández MT. Viral hepatitis and immigration: a challenge for the healthcare system. Rev Clin Esp. 2016;216:248-52.

19. El Bouzidi K, Elamin W, Kranzer K, Irish DN, Ferns B, Kennedy P, et al. Hepatitis delta virus testing, epidemiology and management: a multicentre crosssectional study of patients in London. J Clin Virol. 2015;66:33-7.

20. Wang-Johanning F, Lu DW, Wang Y, Johnson MR, Johanning GL. Quantitation of human papillomavirus $16 \mathrm{E} 6$ and $\mathrm{E} 7$ DNA and RNA in residual material from ThinPrep Papanicolaou tests using real-time polymerase chain reaction analysis. Cancer. 2002;94:2199-210.
21. Le Gal F, Gordien E, Affolabi D, Hanslik T, Alloui C, Dény P, et al. Quantification of hepatitis delta virus RNA in serum by consensus real-time PCR indicates different patterns of virological response to interferon therapy in chronically infected patients. J Clin Microbiol. 2005;43:2363-9.

22. Mederacke I, Bremer B, Heidrich B, Kirschner J, Deterding K, Bock T, et al. Establishment of a novel quantitative hepatitis D virus (HDV) RNA assay using the Cobas TaqMan platform to study HDV RNA kinetics. J Clin Microbiol. 2010;48:2022-

23. Smedile A, Lavarini C, Farci P, Aricò S, Marinucci G, Dentico P, et al. Epidemiologic patterns of infection with the hepatitis B virus-associated delta agent in Italy. Am J Epidemiol. 1983;117:223-9.

24. Sagnelli E, Stroffolini T, Ascione A, Bonino F, Chiaramonte M, Colombo M, et al. The epidemiology of hepatitis delta infection in Italy. Promoting Group. J Hepatol. 1992;15:211-5.

25. Sagnelli E, Stroffolini T, Ascione A, Chiaramonte M, Craxì A, Giusti G, et al. Decrease in HDV endemicity in Italy. J Hepatol. 1997;26:20-4.

26. Gaeta GB, Stroffolini T, Chiaramonte M, Ascione T, Stornaiuolo G, Lobello S, et al. Chronic hepatitis D: a vanishing disease? An Italian multicenter study. Hepatology. 2000;32:824-7.

27. Stroffolini T, Almasio PL, Sagnelli E, Mele A, Gaeta GB. Evolving clinical landscape of chronic hepatitis B: a multicenter Italian study. J Med Virol. 2009;81: 1999-2006.

28. Brancaccio G, Giuberti T, Verucchi G, Levantesi M, Sacchini D, Fattovich G, et al., on behalf of the MASTER-B study group. Epidemiological evolution of chronic hepatitis delta in Italy. An analysis of the Master-B cohort. Dig Liver Dis. 2014;46:12-3.

29. Contini C, Badia L, Cultera R, Grilli A, De Togni A. Epidemiological, clinical and laboratory features of chronic hepatitis $B$ infection in a cohort of immigrant and Italian patients from Ferrara, Italy. Ann Hepatol. 2012;11:862-9.

30. De Paschale M, Manco MT, Belvisi L, Magnani C, Re T, Viganò P, Biagiotti S, et al. Epidemiology of hepatitis D virus (HDV) infection in an urban area of northern Italy. Infection. 2012;40:485-91.

31. Frisch-Niggemeyer W, Kunz C. [Delta virus: now also detected in Austria. A defective virus as a pathogenic agent]. Wien Klin Wochenschr. 1985;97:460-3. German.

32. Horváth G, Tolvaj G, Stotz G, Dávid K. The incidence of hepatitis delta virus infection in chronic liver diseases in Hungary. Acta Med Hung. 1992-1993;49:109-17.

33. Jelić D, Jelić O. Epidemiological characteristics of HBV and HDV chronic liver diseases. Acta Med Croatica. 1994;48:7-13.

34. Mele A, Mariano A, Tosti ME, Stroffolini T, Pizzuti R, Gallo G, et al. SEIEVA Collaborating Group. Acute hepatitis delta virus infection in Italy: incidence and risk factors after the introduction of the universal anti-hepatitis $B$ vaccination campaign. Clin Infect Dis. 2007;44:17-24.

35. Velati C, Fomiatti L, Baruffi L, Piccinini V, Prati D, Reina A, et al. Criteria for hepatitis $B$ virus screening and validation of blood components in Italy: the position of the SIMTI HBV working group. Blood Transfus. 2011;4:1-7.

36. Wedemeyer H. Hepatitis D revival. Liver Int. 2011;31:Suppl 1:140-4.

37. Bielawski KP, Zietkowski D, Charmuszko U, Sikorska K, Stalke P. Hepatitis delta virus infection in chronically HBV-infected patients from northern Poland. Arch Virol. 2006;151:1207-15. 
38. Quaglio G, Ramadani N, Pattaro C, Cami A, Dentico P, Volpe A, et al. Prevalence and risk factors for viral hepatitis in the Kosovarian population: implications for health policy. J Med Virol. 2008;80:833-40.

39. Ho E, Deltenre P, Nkuize M, Delwaide J, Colle I, Michielsen P; Belgian Association for the Study of the Liver. Coinfection of hepatitis B and hepatitis delta virus in Belgium: a multicenter BASL study. Prospective epidemiology and comparison with HBV mono-infection. J Med Virol. 2013;85:1513-7.

40. William Tong CY, Asher R, Toby M, Ngui SL, Tettmar K, ljaz S, et al. A re-assessment of the epidemiology and patient characteristics of hepatitis $D$ virus infection in inner city London. J Infect. 2013;66:521-7.

41. Hirzel C, Wandeler G, Owczarek M, Gorgievski-Hrisoho M, Dufour JF, Semmo N, et al. Molecular epidemiology of hepatitis B virus infection in Switzerland: a retrospective cohort study. BMC Infect Dis. 2015;15:483.

42. Grippon P, Ribiere O, Cadranel JF, Pelletier S, Pillot B, Emerit J, et al. Long-term delta antigenaemia without appearance of delta antibody in two immunodeficient patients. Lancet. 1987;1:1031.

43. Kondili LA, Cuko L, Chionne P, Candido A, Madonna E, Dentico P, et al. Hepatitis $B, C$ and delta virus infections in Albanian patients with chronic liver disease: evaluation of possible changes during the last 10 years. Eur J Gastroenterol Hepatol. 2010;22:167-71.

44. Naoumov NV, Gueorgiev A, Ognyanov M, Maleev A. Infection with hepatitis delta virus in patients with fulminant hepatitis B and chronic HBsAg carriers in Bulgaria. Hepatogastroenterology. 1986;33:49-51.

45. Krogsgaard K, Mathiesen LR, Aldershvile J, Kryger P, Andersson P, Hansson BG, et al. Delta infection and hepatitis B virus replication in Danish patients with fulminant hepatitis B. Scand J Infect Dis. 1988;20:127-33.
46. Pohjanpelto P, Sammalkorpi K, Lahdensivu R. Delta agent in Finland. Scand J Infect Dis. 1985;17:431-2.

47. Manesis EK, Vourli G, Dalekos G, Vasiliadis T, Manolaki N, Hounta A, et al. Prevalence and clinical course of hepatitis delta infection in Greece: a 13-year prospective study. J Hepatol. 2013;59:949-56.

48. Chlabicz S, Grzeszczuk A, Lapiński TW, Prokopowicz D, Panasiuk A. Search for hepatitis delta virus (HDV) infection in hepatitis $C$ patients in north-eastern Poland. Comparison with anti-HDV prevalence in chronic hepatitis B. Eur J Epidemiol. 2003;18:559-61.

49. Ramalho F, Carvalho G, Bonino F, Baptista A, de Moura MC. Clinical and epidemiological significance of hepatitis delta virus (HDV) infection in chronic HBV carriers in Portugal. Prog Clin Biol Res. 1987;234:409-17.

50. Popescu GA, Otelea D, Gavriliu LC, Neaga E, Popescu C, Paraschiv S, et al. Epidemiology of hepatitis $D$ in patients infected with hepatitis $B$ virus in Bucharest: a cross-sectional study. J Med Virol. 2013;85:769-74.

51. Delić D, Gotić M, Ostrić V, Fridman V, Nikolić P, Jemuović L, et al. Epidemiology of hepatitis D virus (delta) infection in Yugoslavia. Liver. 1993;13:302-4.

52. Fernández-Montero JV, Vispo E, Barreiro P, Sierra-Enguita R, de Mendoza C, Soriano $\mathrm{V}$. Hepatitis delta is a major determinant of liver decompensation events and death in HIV-infected patients. Clin Infect Dis. 2014;58:1549-53.

53. Ji J, Sundquist K, Sundquist J. A population-based study of hepatitis D virus as potential risk factor for hepatocellular carcinoma. J Natl Cancer Inst. 2012;104:790-2.

54. Curran RA, O'Neill HJ, Connolly JH. Hepatitis delta virus infection in Northern Ireland 1970-1989. Ulster Med J. 1991;60:159-63. 